\title{
ACCESS AND BENEFIT SHARING UNDER NAGOYA PROTOCOL AND SUSTAINABLE DEVELOPMENT: A CRITICAL ANALYSIS
}

\section{J. Stellina}

\author{
Dr. Stellina Jolly \\ South Asian University, (SAARC) Asst Professor, Faculty of Legal Studies, New \\ Delhi, India, 110023 \\ E-mail: stellinajolly@sau.ac.in
}

\begin{abstract}
The debate over control and ownership of natural and bio genetic resources has a chequered history in International environmental law. Historically genetic resources were considered and acknowledged as part of common heritage of mankind. But with the development of technologies and the heightened north south divide over the issue of sovereign right over natural resources the developing nations became extremely concerned with the exploitation of biological and Genetic resources. Access to benefit sharing (ABS) was considered as an answer to balance the interests of developed and developing nations and to conserve and protect bio diversity. Adopted on October 2010 in Nagoya, Japan by the Parties to the Convention on Biological Diversity (CBD) of 1992, the Nagoya Protocol on Access to Genetic Resources and the Fair and Equitable Sharing of Benefits Arising from their Utilization (NP) has come into force after its 50th ratification on 2013. Nagoya protocol details on procedure for access and benefit sharing, disclosure mechanism, principles of transparency and democracy. The paper analyses the protection of access and benefit sharing envisaged under Nagoya protocol and its possible role in promoting sustainable development in the develoing nations.
\end{abstract}

Key Words: Sustainable Development, Nagoya Protcol, Biological Resources, Bio Diversity.

\section{Introduction}

On October 2010, international community saw the successful adoption of the 'Nagoya Protocol on Access to Genetic Resources and the Fair and Equitable Sharing of Benefits by the parties to CBD. ${ }^{1}$ It has been hailed as one of the momentous and unprecedented legal development and is expected to promote intra and intergenerational equity between developed and developing nations. ${ }^{2}$ Such a sharing mechanism became imperative as the biological diversities are mostly located in developing nations and the technological developments to utilise and tap the potential of these biological diversities are the monopoly of developed north. ${ }^{3}$ To complicate the matter until the end of the last

\footnotetext{
${ }^{1}$ Nagoya Protocol on Access to Genetic Resources and the Fair and Equitable Sharing of Benefits Arising from their Utilization to the Convention on Biological Diversity, Oct. 29, 2010, $\mathrm{UNEP} / \mathrm{CBD} / \mathrm{COP} / \mathrm{DEC} / \mathrm{X} / 1$ of 29. COP 10 Decision X1: X/1.Access to genetic resources and the fair and equitable sharing of benefits arising from their utilization, http://www.cbd.int/decision/cop/?id=12267(Accessed on 3-07-2015)

2 E, Louka, International Environmental law, Fairness Effectiveness and World Order, Cambridge, p 310, 2006.
} 


\section{ACCESS AND BENEFIT SHARING UNDER NAGOYA PROTOCOL AND \\ SUSTAINABLE DEVELOPMENT: A CRITICAL ANALYSIS}

century, genetic resources and biological resources were managed as public domain goods on the basis of the "common heritage"(CHM) concept. ${ }^{4}$ Absence of private appropriation, sharing of benefit mechanism, peaceful use and transmission to future generations forms the characteristic feature of this concept. ${ }^{5}$ The developing countries realised the commercial implications from biological resources and saw the protection of genetic resources as a mechanism for economic development and demanded sovereign rights over natural resources. ${ }^{6}$ They argued for specifying national ownership over genetic resources and use of contracts in the movement of resources between countries. ${ }^{7}$ When the negotiations were progressing under the CBD the biodiversity-rich developing nations had high expectations under the premise that biological resources, being the raw material for the biotechnology, seeds and pharmaceutical industries, are the key to potential development. ${ }^{8}$ The South vehemently clamored for national sovereign rights over biological resources and rejected the attempts by the north to extend the common heritage strategy. ${ }^{9}$ Negotiations leading to CBD attempted to reach a consensus by declaring bio-diversity as a common concern of mankind much to the delight of developing nations. ${ }^{10}$ The preamble of the convention declares bio diversity to be the common concern of mankind. ${ }^{11}$ What are the contours of this concept there are diverging opinions? Boyle suggest that the concept denote that under this approach states can no longer exclusively misuse genetic resources against the interests and concerns of the rest of the world. ${ }^{12}$ Access to Benefit was considered as an apt mechanism through common concern interest of nations can be balanced and was incorporaated as part of conventions objective.

\section{Access to Benefit Sharing and Bio Diversity Protection}

The $\mathrm{CBD}$ is the legal foundation of biodiveristy protection and the ABS mechanism. ${ }^{13}$ The convention has primarily three objectives in the form of (a) conservation of biological diversity, (b) the sustainable use of its components (c) and the fair and equitable sharing of the benefits arising out of the utilization of genetic resources. ${ }^{14}$

3 ibid.

${ }^{4} \mathrm{~B}$, Kemal, The Concept of the Common Heritage of Mankind in International Law, Hague, Martinus Nijhoff, p xxi, 7, 1988

${ }^{5}$ ibid

6 A, Zinatul, L.A, Zainol, Bio Piracy and States Sovereignty over their Biological Resources, African Journal of Bio Technology, Vol. 10, No (58), pp, 12395-12408, 2011.

${ }^{7}$ R,Pistorius, Scientists, Plants, and Politics: A History of the Plant Genetic Resources Movement, United States, Diane Publishing Company,1997.

${ }^{8}$ S, F, H Gurdrun, The Regime Building on the Convention on Biological Diversity on the Road to Nairobi, Max Plank UNYB (3), pp 315-361, 1999.

9 G.K, Rosendal, Interacting international Institutions: Convention on Biological Diversity and TRIPSRegulating Access to genetic resources, Interactions Between International Institutions Synergies and Conflicts,2003,http://www.ecologic.de/download/projekte/850-

899/890/isa/isa_convention_on_biodiversity.pdf accessed on 3-07-2015).

$10 \mathrm{https} / /$ www.cbd.int/gbol/chap-02.shtml. accessed on 3-07-2015

11 U.N. Conference on Environment and Development: Convention on Biological Diversity, June 5, 1992 , U.N. Doc. UNEP/Bio. Div/N7-INC.S/4, reprinted in 31 I.L.M. 818 [hereinafter CBD].

12 A. E, Boyle, M. R, Anderson, Human Rights Approaches to Environmental Protection, Clarenden Press, 1988

13 Supra note 11 , see CBD.

14 ibid 
Regarding ABS commented Tvedt and Young, "nationally, countries committed to enabling access to genetic resources and in exchange for developing countries' agreement to this commitment, developed countries agreed to a second commitment - to develop a mechanism for sharing the benefits of the utilization of genetic resources with the country of origin. In essence, both groups received a desired objective, in exchange for committing to one for which they have less desire." 15

CBD has operationalised ABS mechanism through Article 15. It recognizes the sovereign rights of States over their natural resources, At the same time states are required to create conditions to facilitate access to genetic resources for environmentally sound uses by other Contracting Parties and not to impose restrictions that run counter to the objectives of this Convention. ${ }^{16}$ Access, where granted, shall be on mutually agreed terms and on the basis of prior informed consent. ${ }^{17}$ When the fair and equitable benefitsharing was first adopted as part of CBD, many developing countries saw this as an opportunity of promoting intragenrational equity and hoped that it will put an end to bio piracy and will assist them pursue a path of development. Several countries have developed legal regimes and implementing mechanisms to regulate access to genetic resources ${ }^{18}$ but, unfortunately due to lack of exhaustive provisions of the modalities and mechanisms of benefit sharing jurisdictions came out with their own strategies. The case of Philippines can be cited here. The legal structure envisaged by Philippines was so much protective and restrictive in nature that it almost led to extinction of any possibility of benefit sharing. It was realised that a formal mechanism is the need of the hour. After long years of concerted negotiations which witnessed conflicting arguments and positions the Nagoya Protocol, was adopted at the 10th Conference of the Parties (CoP) to the CBD at Aichi-Nagoya, Japan in October 2010.19

\section{Nagoya Protocol and Sustainable Development}

The Nagoya Protocol implements the third objective of the CBD, concerning fair and equitable sharing of the benefits arising out of the utilization of genetic resources. The scope of the protocol applies to genetic resources, traditional knowledge (TK) associated with genetic resources and the benefits arising from its utilization. ${ }^{20}$ The question which forms the core of the discussion relates to how far Nagoya protocol promotes sustainable development. The international law of sustainable development is contained in a catena of declarations, conventions and other documents. In 1972 International environmental law is believed to have taken its first major step with the convening of first Conference on the Human Environment ("UNCHE"). ${ }^{21}$ The concerns of

\footnotetext{
${ }^{15}$ M. Tvedt, T, Young, Beyond Access: Exploring the Implementation of the Fair and Equitable Sharing Commitment in the CBD, IUCN Environmental Policy and Law Paper No. 67/2, Bonn Germany, IUCN Environmental Law Centre, 2007, http://www.fni.no/doc\&pdf/beyond_access.pdf, accessed on 23-06-2015. 


\section{ACCESS AND BENEFIT SHARING UNDER NAGOYA PROTOCOL AND \\ SUSTAINABLE DEVELOPMENT: A CRITICAL ANALYSIS}

developing countries were addressed and the conference formally linked the issue of environment protection with development. ${ }^{22}$ This was carried forward further when in 1983 General Assembly resolution established the World Commission on Environment and Development ("WCED). ${ }^{23}$ The outcome document popularly known as, "Our Common Future" gave the world a new paradigm of sustainable development. ${ }^{24}$ It defines "sustainable development as a development which seeks to meet the needs and aspirations of the present without compromising the ability to meet those of the future." 25

The idea of sustainable development got a boost and concrete foundation in 1992 with the United Nations Conference on Environment and Development(RIO). ${ }^{26}$ The linkage of environmental conservation measures, economic and social goals got completely entrenched into the sphere of international law with the signing of RIO declaration. ${ }^{27}$ The exact meaning and definition of sustainable development eluded RIO and its implementation was marred by its lack of clarity. Patricia Birnie and Alan Boyle, ${ }^{28}$ identifies following components

- the environmental needs of future generations;

- environmental protection to be an integral part of development;

- common but differentiated responsibilities; reduction of unsustainable patterns of production and consumption;

- enactment of effective environmental laws;

- recognition of the precautionary principle;

- internalization of environmental costs and the use of economic instruments.

The above characteristic features suggest the existence of certain substantive and procedural aspects to the principle of Sustainable development. The substantive elements are the sustainable utilization of natural resources; the integration of environmental protection and economic development; the right to development; and striving for equity in the allocation of natural resources between future and present generations. ${ }^{29}$ The procedural principles deal with public participation in environmental decision-making and environment al impact assessment. ${ }^{30}$ For International Union for Conservation of Nature (IUCN) sustained development refers to processes, principles and objectives as well as to a large body of international agreements on environmental, economic, civil and political rights. ${ }^{31}$ In Gabcikovo-Nagymaros, the International Court of Justice deliberated on the concept of sustainable development as a concept reconciling economic

\footnotetext{
${ }^{22}$ K. Alexandra, S. Dinah, A Guide to International Environmental law, Martinus Nijoff, p 38, 2007.

${ }^{23} \mathrm{Ibid}, \mathrm{p} 39$.

24 ibid

25 ibid

${ }^{26}$ Report of the United Nations Conference on Environment and Development Annex I AICONF.151/26 (Vol. I) Aug. 121992.

${ }^{27}$ P. Pramod, Learning from Ecological Ethnicities: Toward a Plural Political Ecology of Knowledge, in (John A. Grim Ed.) Indigenous Traditions and Ecology: The Inter-being of Cosmology and Community, $\mathrm{p}$ 559-574, 2001.

${ }^{28}$ P. Birnie, A. Boyle, International law and the Environment, Oxford University Press, 2009.

${ }^{29}$ M. Fitsmaurize, Contemporary Issues in International Environmental Law, Edgar Elgar, 2009.

${ }^{30} \mathrm{ibid}$.

${ }^{31}$ Report of a Consultation on Sustainable Development: The Challenge to International Law", Reciel 2(4) (1993).
} 
development with protection of the environment. ${ }^{32}$ Through successive conventions and declaration, juristic opinions certain substantive and procedural components of sustainable development has been identified including right to development, intra and intergenerational equity, precautionary principles and procedural requirements in the form of Public participation, access and information sharing, and principle of transparency and accountability etc.

An analysis of the protocol reveals that attainment of sustainable development figures prominently in the protocol. Protocol broadly incorporates environment, economic and social dimension of the principle of sustainable development. Preamble and objective of the protocol recognises that the fair and equitable sharing of the economic value of biodiveristy with the custodians of biodiversity forms a key part of the the conservation of biological diversity and the sustainable use of its components..$^{33}$ The protocol mandates that benfit shring mechanism envisaged here contributes to the conservation of biodiversity and the sustainable use of its the components. The key components of the Nagoya Protocol are the provisions on access, benefit sharing and compliance. The substantive and procedural components of law of sustainable development are generally incorporated in the attainment of these components.

Access to Genetic Reosurces. Protocol prescribes that access to genetic resources shall be subject to the prior informed consent of the Party (PIC) and on mutually agreed terms (MAT) ${ }^{34}$ The access should be based on legal certainty, clarity and transparency. ${ }^{35}$ Protocol ensures obligations between provider as well as user countries to put in place a mechanism of access based on fairness. Countries should ensure that their obligation to grant access are properly matched with the corresponding obligation on the part of developed countries to ensure compliance and contribute to technological diffusion, as well as funding. ${ }^{36}$ Protocol takes into account social dimension while dealing with access requirements. Protocol urges the states to create conditions of access, which will promote and encourage research contributing to the conservation and sustainable use of biological diversity particularly in developing countries. ${ }^{37}$ It gives due regard to the importance of genetic resources for food and agriculture and their special role for food security. ${ }^{38}$ Protocol provides special attention to the condition of traditional and indegenous communities. Protocol directs that with regard to these community access in terms of genetic resources, State should through legal and administrative measures make sure that for access is obtained from such communities. ${ }^{39}$

\footnotetext{
${ }^{32}$ Gabčíkovo-Nagymaros Project (Hungary/Slovakia),1997 I.C.J. 7, reprinted in 37 I.L.M. 162

${ }^{33}$ Supra note1 see Nagoya preamble \&objective.

${ }^{34}$ ibid, Art 6 (1)

35 ibid, Art 6 (3)

36 An Explanatory Guide to the Nagoya protocol on Access and Benefit Sharing, IUCN, $p$ 28,2012.https://books.google.co.in/books?id=HXW95Za0wk0C\&printsec=frontcover\# $\mathrm{v}=$ onepage \&q \& $\mathrm{f}=$ fal se accessed on 10-06-2015.

37 Supra note 1 See Nagoya, Art 8.

38 ibid, Art 8 (c).

${ }^{39}$ ibid, Art 7.
} 


\section{ACCESS AND BENEFIT SHARING UNDER NAGOYA PROTOCOL AND \\ SUSTAINABLE DEVELOPMENT: A CRITICAL ANALYSIS}

Benefit Sharing: One of the foundational principles of sustainable development is the principle of fairness, equity and justice. Protocol throughout its breadth and length elaborates procedures for achieving a fair and equitable benefits sharing mechanism from the utilization of genetic resources as well as on the subsequent applications and commercialization. ${ }^{40}$ Protocol dicates that benefit sharing includes monetary and non monetary benefits. ${ }^{41}$ This provision if put to implementation properly can provide communities much needed assistance in the form of establishment of hospitals, schools etc leading to sustainable development. Principle of fairness and justice demands that those who conserve the biological resources should benefit from its utilization. ${ }^{42}$ What constitutes a fair and equitable benfit sharing has to be detrmine dby the criteria developed. ${ }^{43}$ Some of the points sugggested include:

- The South-North imbalance in resource allocation and exploitation;

- Protecting the cultural identity of traditional communities;

- A shared interest in food security;

- The need to conserve biodiversity. ${ }^{44}$

Protocol prescribe that benefits derived from the utilisation of genetic resources or traditional knowledge held by communities must be shared in a fair and equitable way with such communities. ${ }^{45}$ From the procedural aspect participation of the relevant stakeholdres is significant. Protocol recognizes the role of indigenous communities in providing, caring and nurturing bio diversity and the necessity to protect biodiversity for the sustainable livelihoods of these communities. ${ }^{46}$ Indigenous people need to be consulted in developing community protocols, minimum requirements for MAT, and model contractual clauses. ${ }^{47}$ Capacity building has been given lot of attention under the protocol. ${ }^{48}$ Protocol emphasizes the need to increase capacities of women and Indigenous communities so that they can effectively participate in the implementation of the protocol. ${ }^{49}$

The provisions protecting and safeguarding the interests of indigenous communities has given a fresh leave of hope into the life of these communities in making sustainable use of bio diversity and thereby contributes to the sustainable development of the society. As Braulio Ferreira de Souza Dias, Executive Secretary of the Convention on Biological Diversity pointed out: "The Nagoya Protocol is central to biodiversity for sustainable development. Its entry into force will create incentives for preserving genetic diversity, biodiversity in general, and associated traditional knowledge. It will provide the conditions for continuous research and development on genetic resources. But most importantly, the Protocol will give us the opportunity to develop an

40 ibid, Art 5 (1).

41 ibid, Art 5 (4)

42 B. De Jonge, What is Fair and Equitable Benefit-sharing, J Agric Environ Ethics Vol. 24, pp 127-146, 2011.

43 ibid

44 ibid

${ }^{45}$ supra note 1 Art $5(2)$

46 ibid, Art 12 (2)

47 ibid Art 12 (3) (a)

48 ibid Art 22

49 UN Secretary-General Report on Legal Empowerment and Poverty Eradication (A/64/133) and UN General Assembly Resolution on Legal Empowerment of the poor emphasise on the rights of indigenous people as a mechanism to tackle poverty and achieve sustainable development. R. Katharina \& K. Koutouki, The Nagoya Protocol: Status of Indigenous and Local Communities, Vermont Journal of international law Vol 13, p513-535, 2011. 
economy that is more sustainable and where the value of natural resources will be truly acknowledged. ${ }^{50}$

Compliance: Protocol elaborates on compliance measures and dispute resolution meausres to be initiated by the parties to see that genetic resources utilized within their jurisdiction have been accessed in accordance with prior informed consent and on mutually agreed terms. ${ }^{51}$ Protocol clearly gives emphasis to the procedural requirement of access to justice. ${ }^{52}$ Protocol mandates an efficient mechanism to seek recourse under their legal systems when disputes arise from mutually agreed terms. ${ }^{53}$

One of the corner stone of sustainable development relates to the right to development and it needs no emphasis that there can be no development without compacting poverty. The capacity of Nagoya protocol to promote sustainable development is directly proportional to its ability to fight and remove poverty. Bio diversity - sustainable development poverty nexus has attracted wide scale of research and discussions across competent academics. ${ }^{54}$ The highest biodiversity hotspots are found in developing countries. Biodiversity hotspots are also characterised by regions of acute poverty. ${ }^{55}$ The complementarily and harmonious existence of the goal of sustainability and poverty reduction is well emphasised in the 2011 Human Development Report which argues argue strongly for the need to consider sustainability and equity jointly. ${ }^{56}$ But if we analyses how far poverty reduction finds its place in Nagoya protocol, the objective of poverty reduction does not find any express mention. ${ }^{57}$ Definitely three are provisions which have a bearing on poverty reduction are scattered in various part of protocols. But the clear-cut absence of a poverty target provisions certainly puts a question mark on the ability of the protocol to achieve sustainable development. There are studies showing the impact of ABS mechanism and poverty reduction. In 1985 US National Cancer Institute (NCI) while researching drugs for HIV did investigation on mamala Tree which the villagers traditionally uses to cure hepatitis. ${ }^{58}$ The NCI research was able to isolate an ingredient known as Prostratin and got a patent for the same. The NCI agreed to give

\footnotetext{
${ }^{50}$ The Nagoya Protocol Heralds a New Era for Sustainable Development, http://blogs.kent.ac.uk/klsllm/2014/12/03/the-nagoya-protocol-heralds-a-new-erafor-sustainable-development-2/ accessed on 5-07-2015

${ }^{51}$ Supra note 1 See Nagoya Art 15 (1) \& 16 (1)

52 ibid Art 18

${ }^{53}$ ibid 15 (2) \& 16 (2)

${ }^{54}$ W. M, Adams, D, Aveling, B. Brockington, J, Dickson, J, Elliot, D. Hutton, B. Roe, B. Vira, and W. Woolmer, Biodiversity Conservation and the Eradication of Poverty. Science Vol 306, pp 1146-1149, 2004.

${ }^{55}$ B. Fisher, T. Christopher, Poverty and Biodiversity: Measuring the Overlap of Human Poverty and the Biodiversity Hotspots. Ecological Economics Vol 62: pp 93-101. 2007.

${ }^{56}$ Human Development Report (2011) Sustainability and Equity: A Better Future for All, New York, UNDP.

${ }^{57}$ Supra note. See Nagoya 1 preamble Recognizes the interdependence of all countries with regard to genetic resources for food and agriculture as well as their special nature and importance for achieving food security worldwide and for sustainable development of agriculture in the context of poverty alleviation.

${ }^{58}$ Towards Access and Benefit-Sharing Best Practice, Pacific Case Studies, Australian Government and Aus Aid, http://www.absinitiative.info/uploads/media/ABS_Best_Practice_Pacific_Case_Studies_Final_01.pdf accessed on 4-062015.
} 


\section{ACCESS AND BENEFIT SHARING UNDER NAGOYA PROTOCOL AND \\ SUSTAINABLE DEVELOPMENT: A CRITICAL ANALYSIS}

$30 \%$ of the royalties to the village in Samoa. The recent studies prove that it has helped to reduce poverty in the region..$^{59}$

Common but Differentiated responsibility principle has been accepted as a component of sustainable development. The access and benefit mechanism under Nagoya is premised on the belief that developing nations holds most of the biological resources. By imposing an obligation on the user countries (mostly developed) to share the benefits derived out of the utilization of biological resources Nagoya protocol operationalize the CBDR principle. In most of the cases this situation may hold true. However, we cannot ignore the fact that there are biologically less diverse developing countries. The underlying point is that merely being a developing country does not make such countries significant beneficiaries of ABS, unless they happen to be also significant holders of genetic diversity. Further contractual relations form the back rope of ABS. Developing nations often does not possess equal bargaining powers compared to the most developed nations negatively impacting CBDR.

Successful implementation of ABS requires a deep level of understanding among the various stakeholders. Most of the developing nations awareness of ABS in government and non-government sectors is extremely low. Programmes and rules needs to be in place to increase awareness and capacity building of government, non-government organizations, civil society, and local communities. Effective implementation of any convention requires the participation of stakeholders and in terms of Nagoya protocol it is the role of common public, which assumes significance. In order to promote meaningful participation of them it is imperative that democratic institutions especially at the local level should be strengthened. Unless and until this happens the real impact of Nagoya protocol in achieving sustainable development will not be materialized.

\section{Suggestions and conclusions}

The notion of sustainable development is a dynamic concept and its right implementation can go a long way in promoting real development among disadvantaged regions and communities. ${ }^{60}$ Without any doubt, the Nagoya Protocol epitomizes an ideal agreement based on the fundamental deep-rooted association between biodiversity and sustainable development. Protocol incorporate many of the substantive and procedural ingredients of sustainable development in the form of access on mutually agreed terms, benefit sharing, participation of indigenous communities and capacity building of women etc. Right to development has been recognised as a prominent goal under the protcol. The protocol on the flipside gives scant regard to poverty reduction. The relation between biodiversity protection, sustainable development and poverty reduction has travelled a long way from just being an environmental issue to encompass social and human right paradigms. ${ }^{61}$ This assumes double significance as many of the hotspots of bio diversity also corresponds with the poorest regions and communities of the world. Poverty reduction and involvement of the disadvantages communities' involvement and a real benefit sharing mechanism is needed if Nagoya Protocol has to have any measurable impact of achieving

\footnotetext{
59 ibid

${ }^{60}$ supra note 28 see Birnie

${ }^{61}$ India Country Strategy Paper, Government of India, 2007.
} 
sustainable development. Nevertheless, given the clash of interests among CBD parties, any kind of agreement is a major step forward. ${ }^{62}$ For nations and communities, protocol offers a unique prospect to protect and conserve biodiversity while initiating a path of development, which is truly sustainable. The Nagoya Protocol therefore merits the support, acknowledgment strict implementation.

\section{References}

1. Alexandra, K, Dinah. S, (2007), A Guide to International Environmental law, Martinus Nijoff.

2. Fisher, B., and Christopher T., (2007). Poverty and Biodiversity: Measuring the overlap of human poverty and the biodiversity hotspots. Ecological Economics 62: pp 93-101.

3. Fitsmaurize, M. (2009) Contemporary Issues in International Environmental Law, Edgar Elgar.

4. Grajal, A. (1999), Bio-Diversity and the Nation State, Regulating Access to Genetic Resources Limits to Biodiversity Research in Developing Countries, Conservation Biology 6-10.

5. Katharina R. Von B \& Konstantia Koutouki, (2011) The Nagoya Protocol: Status of Indigenous and Local Communities, Vermont Journal of international law Vol 13, mp 513-535. Kemal B, (1988), The Concept of the Common Heritage of Mankind in International Law, Hague, Martinus Nijhoff.

6. Louka, E (2006) International Environmental law, Fairness Effectiveness and World Order, Cambridge.

7. M. Tvedt., Young T, (2007) Beyond Access: Exploring the Implementation of the Fair and Equitable Sharing Commitment in the CBD, IUCN Environmental Policy and Law Paper No. 67/2, Bonn Germany, IUCN Environmental Law Centre.

8. Michael R, (2003), Poverty Reduction, Equity and Climate Change: Global Governance Synergies or Contradictions? In Globalisation and poverty reduction Programme, London. Overseas Development Institute.

9. Nijar, G.S, (2010), Nagoya Protocol on Access and Benefit Sharing of Genetic resources: An Analysis, (CebLaw), Center of Excellence for Bio Diversity Law.

10. Patria, Birnie, Alan, B, (2009), International law and the Environment, Oxford.

11. Pistorius, R. (1997). Scientists, Plants, and Politics: A History of the Plant Genetic Resources movement, United States, Diane Publishing Company.

12. Pramod P, (2001) Learning from Ecological Ethnicities: Toward a Plural Political Ecology of Knowledge, in (John A. Grim Ed.) Indigenous Traditions and Ecology: The Inter-being of Cosmology and Community, (p 559-574),

13. Zinatul, A, Zainol, L.A, (2011), Bio Piracy and States Sovereignty over their Biological resources, African Journal of Bio Technology, 12395-12408.

\footnotetext{
${ }^{62}$ Nijar, G. S, Nagoya Protocol on Access and Benefit Sharing of Genetic Resources Analysis and Implementation Options for Developing Countries, South Centre, 2011. http://www.southcentre.int/wpcontent/uploads/2013/05/RP36_The-Nogoya-Protocol_EN.pdf accessed on 21-06-2015.
} 